\title{
INTELLIGENT SYSTEM OF TRAFIC LIGHT CONTROL WITH DYNAMIC CHANGE PHASES OF TRAFFIC FLOWS ON UNCONTROLLED INTERSECTIONS
}

\author{
${ }^{1}$ Moroz B. I., doctor of science \\ ${ }^{I}$ Alekseieiev M. O., doctor of science \\ ${ }^{2}$ Shvachych G. G., doctor of science \\ ${ }^{3}$ Pasichnik A. M., doctor of science \\ ${ }^{3}$ Miroshnichenko S. V., doctor of science \\ ${ }^{1}$ Ukraine, Dnipro, University of Technology, \\ ${ }^{2}$ Ukraine, Dnipro, National Metallurgical Academy of Ukraine, \\ ${ }^{3}$ Ukraine, Dnipro, University of Customs and Finance
}

DOI: https://doi.org/ 10.31435/rsglobal_ws/30112018/6228

\section{ARTICLE INFO}

Received: 18 September 2018 Accepted: 20 November 2018 Published: 30 November 2018

\section{KEYWORDS}

Traffic-light control, time of the traffic light cycle, traffic flow control, intelligent transport system, intersections throughput capacity. \begin{abstract}
There was method of making an effective system of traffic-light control of the traffic through the intersections in one direction according to which the phase coefficients for each cycle of traffic-light control are computed in real-time using the data of traffic intensity detected by transport detectors. Thus, the built-in traffic control system will be dynamically adapted to the change in the intensity of traffic flows, and the structure of the cycle and its duration will be changed taking into account the parameters of the traffic flow at the intersection. Accordingly, the traffic light cycle, where each cycle has the minimum required duration, will be most effective and will ensure uninterrupted traffic, the lack of traffic jams and the convenience for the pedestrian crossings.
\end{abstract}

Citation: Moroz B. I., Alekseieiev M. O., Shvachych G. G., Pasichnik A. M., Miroshnichenko S. V. (2018) Intelligent System of Trafic Light Control with Dynamic Change Phases of Traffic Flows on Uncontrolled Intersections. World Science. 11(39).doi: 10.31435/rsglobal_ws/30112018/6228

Copyright: (C) 2018 Moroz B. I., Alekseieiev M. O., Shvachych G. G., Pasichnik A. M., Miroshnichenko S. V. This is an open-access article distributed under the terms of the Creative Commons Attribution License (CC BY). The use, distribution or reproduction in other forums is permitted, provided the original author(s) or licensor are credited and that the original publication in this journal is cited, in accordance with accepted academic practice. No use, distribution or reproduction is permitted which does not comply with these terms.

Introduction. The growing role of the transport in the society life requires provision of the necessary conditions for ensuring the efficiency and quality of the operation of traffic control systems for urban and long-distance passenger and cargo transportation [1]. At the same time, road transport is the most dangerous in comparison with other means of transport. At present, the death toll in the incidents is about 1.25 million people in the world, great more people are injured. So according to the traffic safety department of the Ministry of Internal Affairs, from 2014 to 2016 in Ukraine, 82,400 accidents were registered with people involved, including 13,32 thousand people killed and 101,5 thousand injured. At the same time, one of the main accident causes is uncontrolled pedestrian crossings - 38\% and violating the rules of intersection crossings - 30\%. According to the World Bank (data of 2014), the loss of the Ukrainian economy from road traffic accidents is about $\$ 4.5$ billion annually [2].

Therefore, the development of new models and methods for improving the traffic-light of the traffic flow control system becomes particularly relevant for optimizing the functioning of urban transport 
networks. To do this, it is necessary to constantly equip the street-road network with modern software and technical means of the traffic control [3]. And accordingly, the development and implementation of intelligent transportation systems is an effective means of improving road safety.

Analysis of recent research and publications. Today, traffic-light of the traffic flow control systems are carried out on the basis of the constant phases of the traffic flow in different directions, computed on the basis of technical parameters, output data and statistics $[4,5]$. The basic parameters, which the traffic-light control system operation is based determine the operating time (signaling) of the traffic light green signal for each direction, the level of loading, the intensity of the flow and the throughput of the intersection. The throughput of the main line at the intersection of the stop line is determined by the bandwidth of one lane, by the lanes number, by traffic organization and the control modes [6].

Progress in the field of computing and mobile communications has created favorable conditions for the development and implementation of intelligent control systems in various fields of business, especially transport [7]. Intelligent transportation systems (ITS) are based on application of modern software and hardware means of registration and real-time processing of data flows on the involved elements operation of the transport infrastructure, including the movement of people and goods.

Currently, one of the priority directions of application of intelligent transportation systems is to ensure road safety. Thus, in order to realize the requirements of the traffic safety for the society, intelligent transportation systems for Ukraine should become an integral part of the transport complex [8].

The importance of further development of the theory and practice of intelligent transportation systems application necessitates the existence of numerous scientific researches on this subject. The intelligent transportation system application in the city network is a significant step forwards the transport system development to European and world levels, as shown in [9], where the simulations and research of traffic flow control problems in the urban transport network was conducted. Fundamental foundations for the development and implementation of ITS are given in [10-12]. In scientific papers [13, 14] an analysis of perspective directions of intelligent transportation systems application was carried out.

One of the most dangerous places in urban transport systems is the presence of a heterogeneous network of street and road intersections in one direction. This is due to the fact that at such intersections, the interaction of traffic flow with road conditions depends on the influence of a large number of factors. Therefore, in order to manage the traffic and pedestrians in such cases, the system of traffic control is used.

The purpose of the paper is to develop a method for traffic-light control at intersections, which provides a reduction in idle time at the intersection in anticipation of the green light due to the dynamic correction of the passage phases duration for vehicles and pedestrians, depending on their number, recorded by the corresponding detectors on their way. The data use on the number of vehicles arriving at the intersection will allow real-time changes in the length of phases of the traffic light control and to make an adaptive system for controlling the traffic through the intersection in one direction. The peculiarity of the presented researches is that this paper highlight the problems of making the intelligent traffic-light control system with the dynamic change of the traffic flows on uncontrolled intersections.

The research results. Intersections by traffic organization are classified as follows: uncontrolled (simple), self-regulated (channelized), adjustable traffic signaling.

On uncontrolled intersections, the technical means of traffic organization are used, that establish the order for both traffic flow and pedestrians, namely: road signs, road markings and guides.

The most effective method of traffic management is the system for regulating traffic through an intersection carried out by an inspector-regulator or a system of traffic lights. The system of traffic lights is one of the most effective ways to improve road safety.

The basic principle of traffic-light control is the application of various methods for the differentiation of traffic flows over time. In this case, the traffic in different directions through the intersection is carried out according to the control phases established by the statistical research data that allows them to streamline their movement and virtually eliminate conflicting situations at the intersections. The regulation phase represents the set of the main and subsequent intermediate traffic light control. The set of all phases of the traffic-light control, which is periodically repeated, forms a cycle of traffic-light control. The traffic light control tactic determines the time during which one or another combination of traffic signals is active. Tactics are divided into main and intermediate. Basic Cycles: Permission (green signal) or prohibition (red signal) of traffic and / or pedestrians in certain directions. An intermediate stroke prohibits the entry to the intersection of new vehicles and provides time to complete the transport maneuver that went to the intersection during the main tact. Intermediate cycles are determined by the following signals of the traffic light: red and yellow; yellow; green and yellow. 
For an uncontrolled intersection of ordinary streets, which are divided into main and secondary ones, the priority passage is provided for the traffic on the main road, while secondary road traffic only moves if there is sufficient time to carry out the maneuver, Fig. 1. That is, the time interval among the cars moving in the main flow $\Delta t_{\text {main }}$ is considered sufficient to perform the maneuvering of the secondary direction vehicle when $\Delta t_{\text {main }}>\Delta t_{m i}$, where $\Delta t_{m i}$ is the marginal interval among vehicles in the flow on the main road when the vehicle is waiting to appear on a secondary road can perform a maneuver of intersection. In the case where $\Delta t_{\text {main }}$ intervals are several times larger than $\Delta t_{m i}$, then several vehicles in a secondary direction may pass through this interval. On the basis of statistical data, the value of the traffic marginal interval among vehicles in the flow on the main street is assumed to be equal $\Delta t_{m i}=6,5 \mathrm{~s}$ [15].

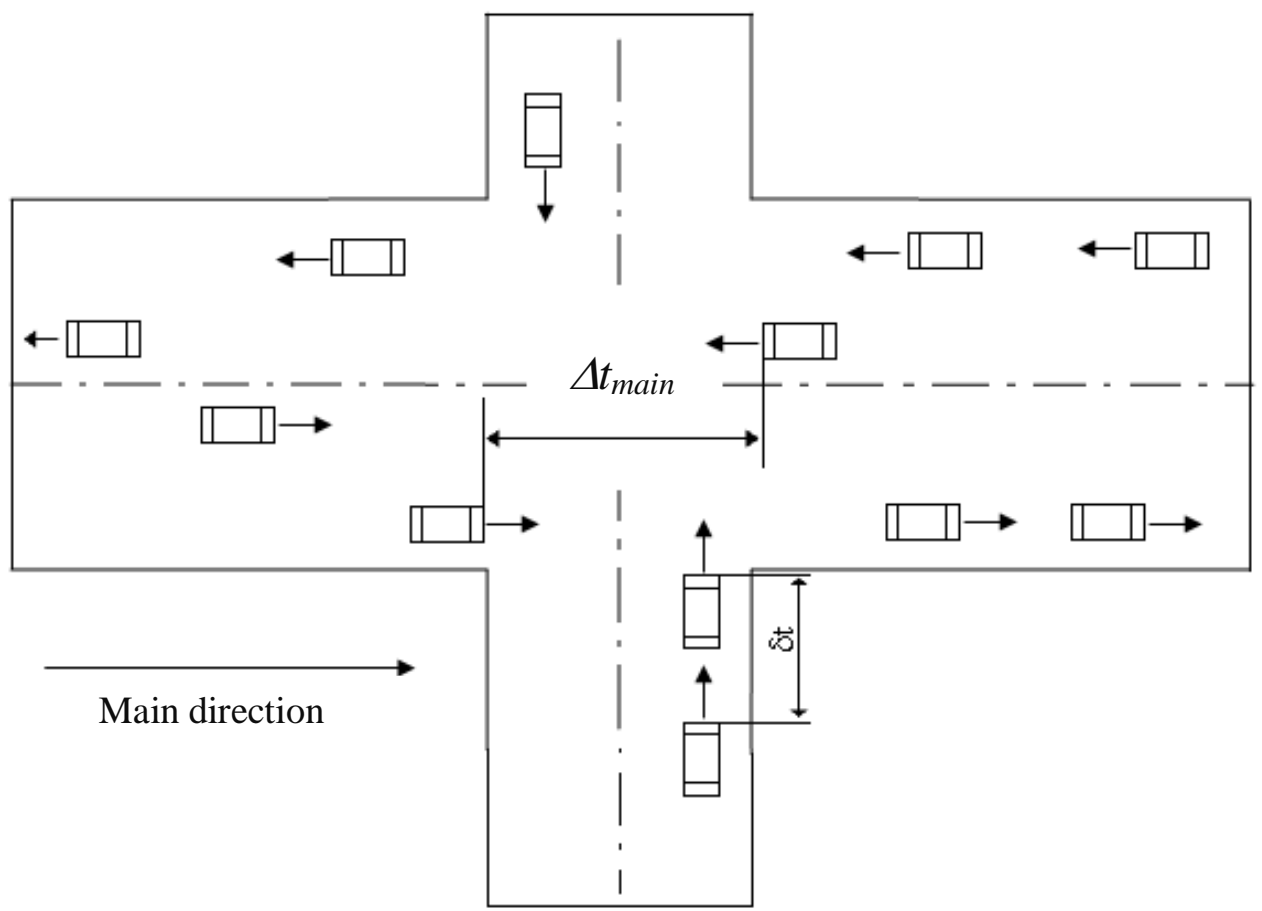

Fig. 1. Traffic arrangement scheme on an uncontrolled intersections.

The total number of all secondary direction vehicles passing through intervals $\Delta t_{\text {main }}>\Delta t_{m i}$, defines the intersection throughput capacity at a given intensity of the main direction. Knowing the distribution function of the intervals in the main stream, one can determine the number of intervals of different durations ( $\Delta t_{\text {main }}$ ) to skip the $i$-th number of vehicles and, therefore, the throughput of the secondary direction by the expression [15].

$$
P_{\text {sec }}=N \cdot e^{-m \Delta t_{\text {гр }}} /\left(1-e^{-m \partial t}\right),
$$

where $P_{s e c}$ is one lane maximum throughput of secondary direction;

$N$ is traffic intensity on the main road in two directions;

$m$ is the mathematical expectation of the number of vehicles in this direction per unit time (in second), is determined by the formula (2);

$\delta t$ - intervals between vehicles entering the intersection of a secondary road. According to [15], $\delta t$ varies from 4.2 to $2.2 \mathrm{~s}$. with an increase in the number of vehicles $\delta t$ decreases, Table 1. 
Table 1. Intervals among vehicles of the secondary direction

\begin{tabular}{|c|c|c|c|}
\hline \multirow{2}{*}{ Interacting flows } & \multicolumn{3}{|c|}{ Length of the fusion line, $\mathrm{m}$} \\
\cline { 2 - 4 } & $30-40$ & $50-75$ & More 150 \\
\cline { 2 - 4 } & \multicolumn{3}{|c|}{ Intervals $\delta t, \mathrm{~s}$} \\
\hline $100 \%$ of trucks & 4,2 & 3,8 & 3,6 \\
\hline $10 \%$ of cars & 4,1 & 3,7 & 3,5 \\
\hline $25 \%$ of cars & 3,95 & 3,55 & 3,3 \\
\hline $50 \%$ of cars & 3,7 & 3,3 & 2,9 \\
\hline $75 \%$ of cars & 3,4 & 3,1 & 2,6 \\
\hline $100 \%$ of cars & 3,1 & 2,8 & 2,2 \\
\hline
\end{tabular}

The value of the limit interval is determined by the vehicles speed in the interlacing zone and the length of the fusion line, Table. 2 [15].

Table 2. The marginal interval value

\begin{tabular}{|c|c|c|c|}
\hline \multirow{2}{*}{$\begin{array}{c}\text { Traffic speed in the intersection zone, } \\
\mathrm{km} / \mathrm{h}\end{array}$} & \multicolumn{3}{|c|}{ Length of the fusion line, $\mathrm{m}$} \\
\cline { 2 - 4 } & 35 & 55 & $130-185$ \\
\cline { 2 - 4 } & \multicolumn{3}{|c|}{ Intervals $\delta t, \mathrm{~s}$} \\
\hline 20 & 9,0 & 8,4 & 7,8 \\
\hline 30 & 7,0 & 5,8 & 4,0 \\
\hline 40 & 7,0 & 4,0 & 3,5 \\
\hline 50 & 9,0 & 6,4 & 4,5 \\
\hline 60 & 12 & 9,0 & 6,8 \\
\hline 70 & - & 12 & 9,2 \\
\hline
\end{tabular}

The mathematical expectation of the number of vehicles in a certain direction per unit of time is determined by the formula

$$
m=N / 3600 \text {. }
$$

The main line throughput at the intersection of the stop line is determined by the bandwidth of one lane, the number of lanes, the traffic and the control mode [16].

In computing the intersection throughput capacity with traffic lights, the following assumptions are taken:

1) all vehicles passing through intersection can be delayed before traffic light;

2) all cars, after turning on green signal, pass through intersection at the same speed and at equal intervals of time.

Under these conditions, the bandwidth of one lane is defined as follows [15]:

$$
P_{t}=\frac{3600 \cdot\left(t_{p}-t_{a}\right)}{T_{c} \cdot t_{i}},
$$

where $T_{c}$ is the time of the traffic light control cycle, s;

$t_{p}$ is duration of the permit signal of the traffic light, s;

$t_{a}$ is time between changing of the green signal of the traffic light and crossing the stop line by the first car, s;

$t_{i}$ is time interval for intersection crossing by a vehicle, $\mathrm{s}$.

According to the observations results the $t_{a}$ is $1-3 \mathrm{~s}$, it is recommended to take in the computations $t_{a}=2 \mathrm{~s}$. The observations value of $t_{i}$ is 6-8 seconds for cars, 10-12 seconds for trucks [15].

Conclusions from this research and prospects for further studies in this direction. The use of traffic control systems can significantly improve the conditions for the traffic and pedestrians through the intersections in one direction. At the same time, the operating modes application of traffic lights with stationary phases of traffic and pedestrians leads to an unreasonably overestimated capacity, and, consequently, additional time losses at traffic lights, reduction of traffic safety, increased fuel consumption and more intense environmental pollution by exhaust gases. 
Existing methods for computing the full cycle of traffic-light control are based on statistical data on the traffic and pedestrians at these intersections with the fixation of their number, type, time, conditions and other parameters.

The most rational way to increase the efficiency and safety of traffic at the intersections is to improve the systems of traffic-light control by introduction of intelligent adaptive control systems. In accordance with the proposed approach, the intelligent traffic control system is based on the phases length of the vehicles passing through intersections computed in real time on the basis of the initial data obtained from the transport detectors on the available queues of cars and pedestrians. The application of such an approach will increase traffic safety and traffic efficiency and pedestrian crossings, as well as reduce traffic accidents and fuel consumption.

It should be noted that the practical implementation of intelligent traffic control systems is a complicated engineering and technical task and requires the concentration problem of mutual efforts of specialists in transport and information technologies.

\section{REFERENCES}

1. Avtomobil'nyy transport Ukrayiny: stan, problemy, perspektyvy rozvytku: monohr. / Derzhavnyy avtotransportnyy naukovo-doslidnyy i proektnyy instytut; za red. A.M. Redzyuka. - K.: DP «DerzhavtotransNDIproekt», 2005. - $400 \mathrm{~s}$.

2. Avariynist' na dorohakh Ukrayiny u 2014 - 2017 rr. [Internet source]: Available at: https://ru.slovoidilo.ua/2017/05/04/infografika/obshhestvo/statistika-dtp-ukraine-samaya-vysokayasmertnost-dorogax-vsex-stran-evropy.

3. Stratehichnyy plan rozvytku avtomobil'noho transportu ta dorozhn'oho hospodarstva na period do 2020 roku. Nakaz Ministerstva infrastruktury Ukrayiny 21.12.2015 roku № 548/ https://mtu.gov.ua//

4. Rudzins'kyy V.V. Intelektual'ni transportni systemy avtomobil'noho transportu: navch. posibnyk / V.V. Rudzins'kyy.- Zhytomyr : ZHDTU, 2012. - 98 s.

5. Klynkovshteyn H.Y. Orhanyzatsyya dorozhnoho dvyzhenyya [Tekst]: uchebnyk dlya vuzov 5-e yzd., pererab. y dop./H.Y. Klynkovshteyn, M.B. Afanas'ev. - M.: Transport, 2001. - 247 s.

6. Pasichnyk A. M. Intehrovani transportni systemy [Tekst] : navch. posib. 2-he vyd. UMSF, 2016. - $168 \mathrm{~s}$.

7. Rudzins'kyy, V. V. Aspekty stvorennya intelektual'nykh transportnykh system avtomobil'noho transportu Ukrayiny / V. V. Rudzins'kyy, O. V. Rudzins'ka // Visnyk ZHDTU. 2014. № 2 (69). - S.181-184.

8. Fil Sayeh, Fil Charl'z. Intelektual'ni transportni systemy. Stiykyy rozvytok transportnoyi systemy: zb. mater. dlya politykiv mist. GTZ, 2007. - 40. s.

9. Mykheeva T. Y. Postroenye matematycheskykh modeley ob"ektov ulychno-dorozhnoy sety horoda s yspol'zovanyem heoynformatsyonnykh tekhnolohyy // Ynformatsyonnye tekhnolohyy. 2006. №1. S.69-75.

10. Kir"yanov O. F. Informatsiyni tekhnolohiyi na avtomobil'nomu transporti: navch. posib. O. F. Kir"yanov, M. M. Moroz, YU. O. Boyko, Kremenchuts'kyy nats. un-t im. M.Ostrohrads'koho. Kharkiv: Drukarnya Madryd, 2015. - 270 s.

11. Jesse Russell. Intelligent Transportation Systems. VSD, 2012. - 110 p.

12. Mashurur A. Chowdhury, Adel W. Sadek. Fundamentals of Intelligent Transportation Systems Planning. Artech House, 2003. - 210 p.

13. Joseph S. Sussman. Perspectives on Intelligent Transportation Systems. Springer, 2005. -229 p.

14. Riccardo Mogre. Intelligent Transportation Systems: A Private Organizations Perspective LAP Lambert Acad. Pub., 2010. - 156 p.

15. Bulavina L. V. Rozrakhunok propusknoyi zdatnosti mahistraley i vuzliv / L. V. Bulavina. - Yekaterenburh: DNZ VPO UDTU, 2009. - $44 \mathrm{~s}$.

16. Lobashov O. O. Praktykum z dystsypliny «Orhanizatsiya dorozhn'oho rukhu»: navch. posib. / O. O. Lobashov, O. V. Prasolenko; Khark. nats. akad. mis'k. hosp-va. - KH. : KHNAMH, 2011. - 221 s. 